$\begin{array}{llll}\text { AL-Qadisiya Journal of Vet.Med.Sci. } & \text { Vol./10 } & \text { No./1 }\end{array}$

\title{
Microbiological study of Otitis externa in Sheep in Diwaniya City
}

\author{
S.A.Ali \\ Coll. of Vet.Med. /Univ of Al-Qadisiya
}

Abstract

In this study, twenty eight Awassi sheep suffering from otitis externa were examined for isolation and identification of bacterical infections. The study showed 53.6\% of the sheeps were positive for bacterical islates. The results showed that Pseudomonas aeruginosa was the most common bacteria $(39,1 \%)$ followed by Staphylococcus aureus $(26 \%)$, Mannheimia haemolytica and Staphylococcus epidermidiis (13\%) for each,while E.coli and Streptococcus spp. were less in common (1\%) for each. Sensitivity tests of these isolate were studied and show highly sensitivity to ciprofloxacin and norfloxacin and highly resistant to Ampicillin.

\section{Introduction}

Otitis externa is a common disease in Cattle, Pigs and small animals $(1,2)$ but it is susceptible in lambs $(3,4)$.Otitis externa is an inflammation of the outer ear and ear canal characterized by an inflammation of the epithelium of the external auditory meatus $(5,6)$. Clinical signs such as exudates in conjunction with the isolation of bacterial species in large number are significance in most cases and may indicate the presence of pathogen $(7,8)$.Otitis externa has a multifactorial etiology and bacteria

\section{Material and Methods}

Sterile cotton swabs were used for collection of specimens from 28 animals suffered from Otitis externa (auricular discharge,weakness,cough,bilateral nasal discharge) and transported to the laboratory.All specimens obtained were cultured for isolation and identification of the bacteria on the following media: -

1.Blood agar.

2. Mac Conkey agar.

3.Chocolate agar.

4.Peptone water.

5.MR-VP media.

\section{Results and Discussion}

A total of 28 Awassi sheep were suffered from Otitis Externa (auricular discharge, weakness, cough, bilateral nasal discharge) were enrolled in this study.The results showed that $15(53.6 \%)$ animals were play an important role in otic disease $(4,5)$. Most of the bacteria incriminated in ear infections include Staphylococcus spp., Pseudomonas spp., E.coli , Mannheimia haemolytica and Proteus can be recovered occasionally $(9,10)$.In Iraq, there are little studies on the Otitis exerna in sheep; therefore the purpose of this study was to determine the bacterial agents that cause Otitis externa in sheep and its sensitivity to antibiotic.

6.Triple sugar iron.

7.Urea medium.

8.Muller-Hinton ager.

The reagents used for identification:-

1.H2O2 (catalase test)

$2.1 \%$ tetra-methyl paraphynl diamine dihydrochloride (oxidase test).

3.Kovac's reagent (indole test).

4.Gram's stain.

5.Antibiotic disc.

Bacteria isolates were identified according to Quinn et al (12).

infected with bacterial species.Twenty three bacterial isolates were isolated from 15 specimens according to biochemical tests (Table 1). 
Table (1) Biochemical reactions characteristic of bacterial species isolates

\begin{tabular}{|l|c|c|c|c|c|c|}
\hline Bacterial isolates & $\begin{array}{l}\text { Catalase } \\
\text { production }\end{array}$ & $\begin{array}{l}\text { Oxidase } \\
\text { production }\end{array}$ & $\begin{array}{l}\text { Indole } \\
\text { production }\end{array}$ & $\begin{array}{l}\text { MR } \\
\text { reaction }\end{array}$ & $\begin{array}{l}\text { Vp } \\
\text { reaction }\end{array}$ & $\begin{array}{l}\text { Urease } \\
\text { test }\end{array}$ \\
\hline $\begin{array}{l}\text { Pseudomonas } \\
\text { aeruginosa }\end{array}$ & + & + & - & - & - & + \\
\hline $\begin{array}{l}\text { Staphylococcus } \\
\text { aureus }\end{array}$ & + & $/$ & $/$ & - & + & \pm \\
\hline $\begin{array}{l}\text { Mannheimia } \\
\text { haemolytica }\end{array}$ & $/$ & + & - & $/$ & $/$ & \\
\hline Staph. epidermidis & + & - & $/$ & $/$ & $/$ & + \\
\hline Escherichia coli & + & - & + & + & - & - \\
\hline Streptococcus spp. & + & - & $/$ & $/$ & $/$ & - \\
\hline
\end{tabular}

As it shown in Table (2) P.aeruginosa were the predominant bacteria $9(39.1 \%)$ followed by S.aureus 6(26\%) and Manheimia haemolytica $3 \quad(13 \%)$
,S.epidermidis 3(13\%) while E.coli and streptococcas spp. were less common $1(4.35 \%)$ for each.

Table (2) Number and percentage of bacterial isolates from ear canal

\begin{tabular}{|l|c|c|}
\hline Bacterial species & Number of isolates & $\%$ \\
\hline Ps. aeruginosa & 9 & 39.13 \\
\hline Staphylococcus aureus & 6 & 26.08 \\
\hline Staph. epidermidis & 3 & 13.04 \\
\hline M.haemolytica & 3 & 13.04 \\
\hline Escherichia coli & 1 & 4.35 \\
\hline Streptococcus spp & 1 & 4.35 \\
\hline Total & 23 & 99.99 \\
\hline
\end{tabular}

The results confirm the results obtained by (4, 7, 9 and 11) who reported that Pseudomonas was the predominant microorganism followed by S.aureus.
Antimicrobial susceptibility tests were determined by Kirby-Baur disc diffusion method (13) .Table (3) showed the results of sensitivity test of the bacterial isolates. 
Table (3) antibiotic sensitivity results of the bacterial species

\begin{tabular}{|c|c|c|c|c|c|c|}
\hline $\begin{array}{l}\text { Bacterial } \\
\text { species }\end{array}$ & $\begin{array}{l}\text { Ps. } \\
\text { aeruginosa }\end{array}$ & $\begin{array}{l}\text { S. } \\
\text { aureus }\end{array}$ & S.epidermidis & M.haemolytica & $\begin{array}{l}\text { E. } \\
\text { coli }\end{array}$ & Streptococcus \\
\hline Ampicilin & $\mathrm{R}$ & $\mathrm{R}$ & $\mathrm{R}$ & $\mathrm{S}$ & $\mathrm{R}$ & $\mathrm{S}$ \\
\hline chloramphinicol & $\mathrm{R}$ & $\mathrm{R}$ & $\mathrm{R}$ & $\mathrm{R}$ & $\mathrm{R}$ & $\mathrm{S}$ \\
\hline Erthromicin & $\mathrm{R}$ & $\mathrm{S}$ & $\mathrm{S}$ & $\mathrm{S}$ & $\mathrm{R}$ & $\mathrm{S}$ \\
\hline gentamicin & $\mathrm{R}$ & $\mathrm{S}$ & $\mathrm{S}$ & $\mathrm{S}$ & $\mathrm{S}$ & $\mathrm{S}$ \\
\hline norfloxacin & $\mathrm{S}$ & $\mathrm{S}$ & $\mathrm{S}$ & $\mathrm{S}$ & $\mathrm{S}$ & $\mathrm{S}$ \\
\hline ciprofloxacin & $\mathrm{S}$ & $\mathrm{S}$ & $\mathrm{S}$ & $\mathrm{S}$ & $\mathrm{S}$ & $\mathrm{S}$ \\
\hline vancomicin & $\mathrm{R}$ & $\mathrm{R}$ & $\mathrm{S}$ & $\mathrm{R}$ & $\mathrm{R}$ & $\mathrm{S}$ \\
\hline
\end{tabular}

It was found that P.aeruginosa was highly resistant to ampicillin chlorampenical and erythromycin but showed highly sensitivity to ciprofloxacin and norfloxacin which confirm the results obtained by (14, 15).S.aureus showed highly sensitivity to ciprofloxacin and norfloxacin and erythromycin but was highly resisted to ampicillin and chloramphinical .All isolates were highly sensitive to Ciprofloxacin \& norfloxacin because of the ability of these antibiotics to inhibit the bacterial DNA gyrase which is very important in stationary growth phase of the bacteria (15).A little is known about otitis extrerna in sheep compared with the information available on cattle and horses and many factors can predispose sheep to otitis extrerna including the anatomic orientation of the ear canal itself .The vertical canal slopes medially into horizontal orientation on the outside of the tympanic membrane .This prevents drainage of debris leads to accumulate it (3).Many bacterial species commonly inhibit the ear canal and can become secondary opportunistic invaders when conditions are favorable $(5,6,9$, and 16).

\section{References}

1. Blue,J.L.,Wooleym, R.E. and Eagong, R.J. (1974). Treatment of experimentally induced Pseudomonas aeruginosa in otitis externa in the dog.Am. J. Vet. Res.35:22-1223.

2. Fossum, T.W. (1997). Otitis externa. In Fossum T.W. Small Animal Surgery. Mosby Year Book Inc. Missouri. 163-168.

3. Pugh DG. Sheep and Goat Medicine. 4th ed. Philadelphia: WB Saunders Com. 2000.

4. Ismail SF. Studies on some surgical affections of the external ear in farm animals. Assuit Vet Med J 1994; 32: 177-187.

5. August, J.R. (1988): Otitis externa, a disease of multifactorial etiology.
Vet. Clin. North. Am. Small Anim. Pract.18, (4), 731-742.

6. Foster,B.;\& Smith, C.(2010). Ear infection (Otitis infections) \& ear cleaning in dogs.

7. Duarte ER and Hamdan JG. Otitis in cattle, An aetiology review. J Vet. Med. 2004; 5: 1 - 7 .

8. Yeruham D, Elad ML. Clinical and Microbiological study of an otitis media outbreak in calves in a dairy herd. J Vet Med 1999; 46: 145-150.

9. Harry H, Mada C, Rober P. Update on antimicrobioal susceptibilities bacterial isolates from canine and feline otitis externa. Can Vet J 2006; 47: 253-255.

10. Watson PJ, Watabe M, Moore JE. Purulent rhinitis and otitis caused by Pseudomonas aeruginosa in 
sheep showed with contaminated shower wash. Vet Rec 2003; 153: 704-707

11. Al-Farwachi, M. I. and M. M. Al-Hassan (2008). Clinical and microbiological study of otitis externa in sheep. Iraqi Journal of Veterinary Sciences, Vol. 22, No. 1, 2008 (43-48).

12. Quinn, P.J; Cartet, M.E.; Markey, B.K; Donlet, W.J.; Leonnard and F.C.;Maghire,D. (2002). Veterinary microbiology and microbial disease. Blackwell publishing company.

13. Bauer, A.W. ; Kirby , W.M. ; Sherris , J. C. and Turck ,M. (1966). Antibiotic susceptibility testing by
A standardized single disk method. Am, J. Chem . Pathol .95 : 493 - 496.

14. Al Zayadi,A.A.N and jawad, R.A.H (2009). isolation of causative bacteria from respiratory infections in pre weaning in calf at Samawa city. Al Qadisyia journal for vet. science .v:8.no:1.

15. Donald, M.M.(1998) clinical textbook for veterinary technicians $4^{\text {th }} \mathrm{ed}$. Philadelphia London diagnostic Samhing and treatment techniques. p.217.

16. Jensen R, Pierson RE, Weibel JL, Tucker JO, Swift BL. Middle ear Infection in feedlot lambs. J Am Vet Med Assoc 1982; 181: 805-807.
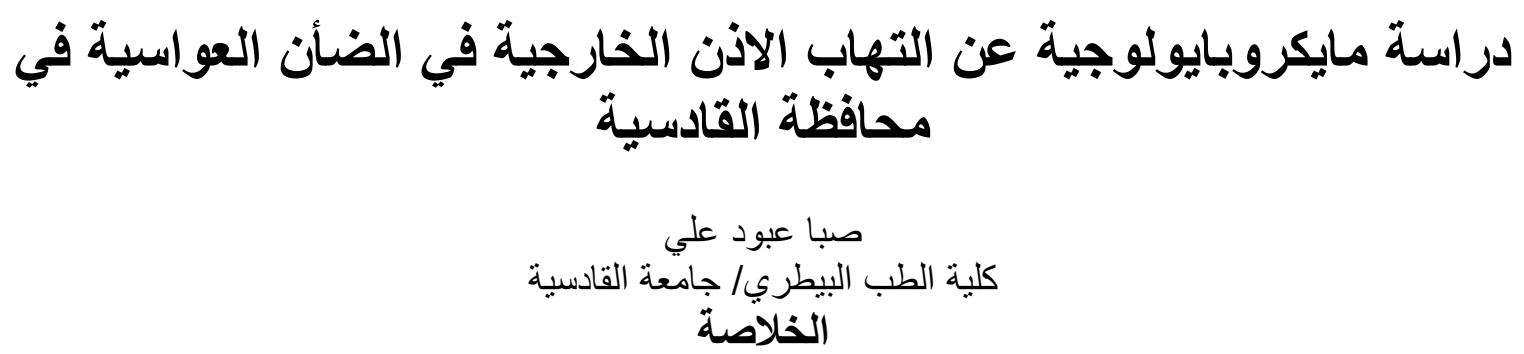

تم في هذه الدراسة فحص 28 رأسا من الضأن العواسيه تعاني من التهاب الاذن الخارجية مايكروبايلوجيا حيث تم

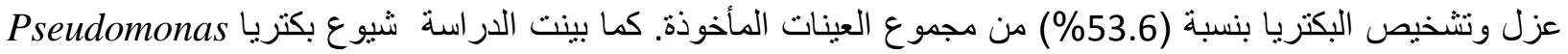

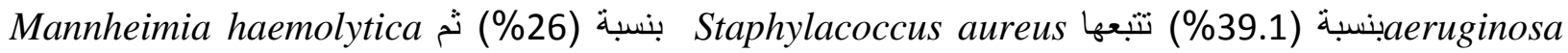
Streptococcus spp g.coli بنسبه (13\%) لكل منهما بينما كانت بكتريا (\%) Staphylococcus epidermidis and

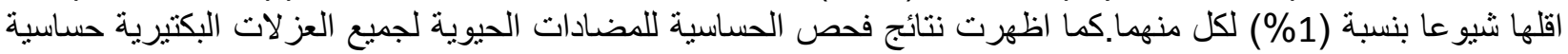

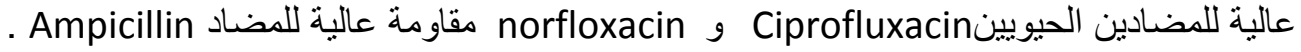

